\title{
Russian Discourse on Borders and Territorial Questions - Crimea as a Watershed?
}

\author{
Tuomas Forsberg \\ Helsinki Collegium for Advanced Studies \& Tampere University \\ tuomas.forsberg@helsinki.fi \\ Sirke Mäkinen \\ Aleksanteri Institute, University of Helsinki \\ sirke.makinen@helsinki.fi
}

\begin{abstract}
This article addresses the question of how the Crimean case relates to Russia's general understanding of territorial questions and border regimes. We examine the historical evolution of Russian discourse on borders and territorial questions and investigate to what extent they can explain Russia's decision to annex Crimea. We will look into the principles of inviolability of borders and territorial integrity that sustain the status quo, and how this has been challenged by three partly interlinked doctrines: national self-determination, geopolitics, and historical rights. We argue that the discourse on territorial integrity and the status quo has predominated in Russia since the Cold War, and that this has not changed fundamentally, either before or after the annexation of Crimea. Russia does not seem to want to abolish the existing norms altogether or to advocate any clearly articulated reformist agenda. Rather, it picks and chooses arguments on an ad hoc basis, imitating Western positions in some other cases when departing from the basic norm of the status quo. Hence, we claim that Russia's territorial revisionism is reactive, self-serving, and constrained by the desire to avoid changing the status quo doctrine to any great extent.
\end{abstract}

\section{Keywords}

Russia - borders - territorial integrity - national self-determination - historical rights 
Russia's annexation of Crimea (or the unification of Crimea with Russia as the Russians prefer to call it) in March 2014 can be seen as a turning point not only in Russia's relations with the West but also in Russia's own policy with regard to international borders. After a long era of status quo maintenance since the end of the Second World War, Crimea was the first case of direct annexation (although technically it can be seen as consisting of a secession first and then a merger) and it has therefore challenged the existing border regime based on status quo much more radically than the earlier cases. Russia is under the loupe here, since a country's policy towards territorial questions and border regimes has always been the ultimate litmus test of whether the country in question is regarded as a norm-abiding member of the international community. As Dmitri Trenin has argued, "Russia's attitude towards borders, no less than anything else, will help define its identity, role in the world and relations with neighbours". ${ }^{1}$

This article addresses the question of how the Crimean case relates to general Russian understanding of territorial questions and border regimes. Does it represent a shift in the way Russian thinking about legitimate territorial changes, or is it an exception that Russia cannot support by consistent normative rhetoric? Is there a more long-term pattern of normative argumentation that backs up Russian politics? The point here is not the perspective of international law and legality as such, but rather the larger political discourse dealing with territorial norms and border regimes. It is important to think how public discourses of borders and territorial questions are related - and perhaps partly even explain - Russia's decision to annex Crimea, or whether such discourses and actual political decisions are only loosely connected. ${ }^{2}$

Although the Crimean case has been widely covered, there is relatively little previous research examining the evolution and structure of Russian discourse on territorial and border issues in general. The received wisdom is that geopolitical discourse gained prominence in Russia as a result of the identity crisis

1 Dmitri Trenin, The End of Eurasia: Russia on the Border between Geopolitics and Globalization (Washington D.C.: Carnegie Endowment for Peace, 2002), 18.

2 On Russian legal interpretations, see Christer Pursiainen and Tuomas Forsberg, 'The Principle of Territorial Integrity in Russian International Law Doctrine: The Case of Crimea', in P. Sean Morris (ed.), Russian Discourses on International Law: Sociological and Philosophical Phenomenon (Routledge: Abingdon 2019), 220-241. 
caused by the break-up of the Soviet Union. ${ }^{3}$ The role of geopolitical identity discourses has been regarded as central to the background of the Ukraine crisis and the annexation of Crimea. Hopf argues that the evolution of the discourses on Russian national identity explains how the annexation of Crimea and Russia's military intervention became thinkable and natural by 2014. ${ }^{4}$ What is lacking, however, is a more systematic understanding of the evolution of normative discourses justifying territorial changes.

There are three different basic accounts of the way in which Russian views on territorial norms and principles can be characterized: realpolitik (instrumentalist), restorative (status quo) and reformist (revisionist). ${ }^{5}$ According to the realpolitik account, Russia's policy is neo-imperial and geared toward territorial expansionism whenever it has power to do so. ${ }^{6}$ Territorial claims are not necessarily related to public discourse at all, since the tendency is seen as innate in the Russian state structures, political culture, geopolitical laws, or even DNA. ${ }^{7}$ Indeed, if Russia is a neo-imperial power intent upon territorial enlargement, all normative argumentation is simply a pretext for self-interest. Adherence to territorial norms is temporary at best and instrumental during times when Russia is weak. For example, Becker, Cohen, Kushi and McManus claim that Russia has been reluctant to accept political institutions established by Western powers when it was weak and is now keen to overthrow the status quo in favor of a new world order more conducive to Russia's rising international status. ${ }^{8}$

3 Edith Clowes, Russia on the Edge: Imagined Geographies and Post-Soviet Identity (Ithaca: Cornell University Press, 2011); Alexander Astrov and Natalia Morozova, 'Russia: Geopolitics from the Heartland', in Stefano Guzzini (ed.), The Return of Geopolitics in Europe? Social Mechanisms and Foreign Policy Identity Crisis (Cambridge: Cambridge University Press, 2012), 192-216.

4 Ted Hopf,'“Crimea is Ours": A Discursive History', International Relations 30 no. 2 (2016), 227-255.

5 Roy Allison, 'Russia and the post-2014 International Legal Order: Revisionism and Realpolitik', International Affairs 93 no. 3 (2017), 519-543.

6 See, for example, Agnia Grigas, Beyond Crimea: The New Russian Empire (New Haven: Yale University Press, 2016) and Ostap Kushnir, Ukraine and Russian Neo-Imperialism: The Divergent Break (Lanham: Lexington Books, 2018).

7 See, for example, Andrei Tsygankov, Russophobia: Anti-Russian Lobby and American Foreign Policy (New York: Palgrave, 2009).

8 Michael E. Becker, Matthem S. Cohen, Sidita Kushi and Ian P. McManus, 'Reviving the Russian Empire: the Crimean Intervention through a Neoclassical Realist Lens', European Security, 25 no. 1 (2015), 112-133. 
The opposing view is restorative and holds that Russia has been a status quo power with regard to borders. It claims that the prominent Russian political and legal discourse has supported state sovereignty and the principle of the inviolability of borders. From this perspective, Russian behavior in Ukraine and Georgia is reactive and defensive in nature, and ultimately aims at defending the existing norms. For Sakwa "the essence of [Russian] neo-revisionism is not the attempt to create new rules or to advance an alternative model of international order but to ensure the universal and consistent application of existing norms". 9

The third option - that Russia is a reformist power with a consistent scheme for a new territorial regime - has been largely absent. It is difficult to find an articulated position of a set of alternative rules beyond the former Soviet Union. Yet, Konyshev and Sergunin have argued that "Russia is neither a status quo state aiming to preserve the main rules of the international system nor a revisionist state that aspires to radically change those rules". ${ }^{10}$ In other words, Russia is a reformist state which is unsatisfied with the existing rules of the 'game' but does not want to change them too much.

We will argue that the discourse sustaining the territorial integrity of states and the status quo of existing borders has predominated in Russia since the Cold War, and that this has not changed fundamentally either before or after the annexation of Crimea. The Crimean case, however, highlighted three partly interlinked challenging doctrines: national self-determination, strategic needs based on geopolitics, and historical rights. In addition to the Ukrainian crisis, the cases of South Ossetia and Abkhazia famously demonstrated the ascendancy of the self-determination discourse in Russia. In addition, historical rights and geopolitical arguments to justify Russia's right/duty to expand its borders and foster post-Soviet integration have been part of the Russian discourse justifying border changes. All these justifications have, however, been selectively employed and have not superseded the principle of status quo as the basic discourse. Indeed, Russia does not seem to advocate any clearly articulated reformist agenda, but its leaders and other representatives pick and choose arguments on an ad hoc basis when departing from the basic norms of territorial integrity and the status quo. We claim that Russia's territorial

Richard Sakwa, Russia against the Rest: The Post-Cold War Crisis of World Order (Cambridge: Cambridge University Press, 2017), 131. See also, Richard Sakwa, 'Russian NeoRevisionism', Russian Politics 4, no. 1, (2019): 1-21.

Valery Konyshev and Alexander Sergunin, 'Russian Views on the Ukraine's Crisis', Valdai Discussion Club (2014), available at: \{http://valdaiclub.com/a/highlights/russian_views _on_the_ukraine_s_crisis/\}, accessed 31 January 2019. 
revisionism is reactive, self-serving, and constrained by the desire to avoid changing the status quo doctrine to any great extent.

\section{Russia's Discourse on Border Regimes and Principles}

The existing international border regime is based on the status quo: state borders should not be changed. In Europe, this was confirmed in the 1975 OSCE declaration which, however, left the back door open to peaceful territorial changes based on mutual consent. Nevertheless, the declaration implied a ban on territorial claims, upon which negotiations on peaceful territorial changes could have been based. The end of the Cold War brought well-known changes to the European territorial order. Germany was unified and three states: the Soviet Union, Czechoslovakia and Yugoslavia were dissolved. Out of these cases, Yugoslavia was the most problematic because the dissolution was not based on the agreement of the dissolving units and led to diverging policies of recognition. The international community nevertheless established a principle, according to which entities of a federal state can be recognized as independent states within their previous administrative borders if they fulfill certain conditions of statehood and democracy. The Kosovars' case stressed that minorities have a right to self-determination if their rights are suppressed by the state, and the recognition could be seen as a way to stabilize the political situation. This principle was, however, vaguely formulated and it was ultimately based on political decisions and state practice on the bases of which the new norms were constructed. ${ }^{11}$

The post-Cold War territorial norms regarding secession and state recognition were therefore ambiguous and contested particularly as far as dissolving federal states were concerned. Some scholars, such as Eiki Berg and Martin Molder have argued that "blurring is the new norm". 12 There is no codified right to secede, but a number of new states have been recognized against the opinion of the parent state. Yet, blurring is relative. Although there remains a margin of normative and factual interpretation concerning each case, there has been no intention to erode the existing border regime and to destabilise

11 Peter Radan, The Break-up of Yugoslavia and International Law (London: Routledge, 2002) and Marko Milanovic and Michael Wood (eds), The Law and Politics of the Kosovo Advisory Opinion (Oxford: Oxford University Press, 2015).

12 Eiki Berg and Martin Mölder, 'When "Blurring" Becomes the Norm and Secession is Justified as the Exception: Revisiting EU and Russian Discourses in the Common Neighbourhood', Journal of International Relations and Development, 17 no. 4 (2014), 469-488. 
the existing territorial order by the majority of the states and the international community. In particular, direct annexation and changes of state borders between existing states without mutual consent - not to mention by the use of force or with the threat of it - are categorically excluded.

Of course, status quo - no changes in borders - does not need to be the only possible or justifiable form of a border regime. Typically, status quo thinking is supported by those states who have no territorial claims but are satisfied with the existing borders. Territorial claims and peaceful change of borders can be justified by various arguments: most typical are those of national self-determination, historic rights, and various geopolitical reasons based on defensive needs, natural borders or pure power political logic, which can be turned into a normative justification in terms strategic needs of great or rising powers. ${ }^{13}$ All these types of arguments come in the different forms. In the case of national self-determination, the critical question is "what is the nation?" and who is the agent that determines its boundaries? With regard to historic rights, the key question is whether historical ownership as such matters, or whether the point is an illegal transfer that took place in the past. The geopolitical arguments that are based either on the view of the organic growth of states and thus some natural, legitimate rights of rising powers or on some idea of natural geographical barriers as borders, in turn, cannot be based on an undisputed view of what "natural" in these cases means.

The annexation of Crimea sparked a huge body of literature dealing with the decision, its motivation, its justification, and its significance to Russia's identity, foreign policy, and the international system. ${ }^{14}$ Focusing on the official

13 See, Tuomas Forsberg, 'Territorial Disputes and the Possibility of Peaceful Change', in Heikki Patomäki (ed.), Peaceful Changes in World Politics (Tampere: Tampere Peace Research Institute, 1995), 122-167. and for example, Norman Hill, Claims to Territory in International Law and Relations (New York: Oxford University Press, 1945).

14 Brad Simpson, 'Self-Determination in the Age of Putin', Foreign Policy Online (March 21 2014), available at: $\{\mathrm{http} / /$ foreignpolicy.com/2014/o3/21/self-determination-in-the-age-of -putin/\}, accessed 31 January 2019; Igor Zevelev, 'The Russian World Boundaries. Russia's National Identity Transformation and New Foreign Policy Doctrine', Russia in Global Affairs, no. 2 (2014), available at: \{http://www.globalaffairs.ru/number/The-Russian-World -Boundaries-16707\}, accessed 31 January 2019; Mikhail Deliagin, 'Crimea', Russian Politics \& Law, 53, no. 2 (2015), 6-31; Flemming Splidsboel Hansen, 'Framing Yourself into a Corner: Russia, Crimea, and the Minimal Action Space', European Security, 24, no. 1 (2015), 141-158; Marlene Laruelle, 'Russia as a "Divided Nation," from Compatriots to Crimea: A Contribution to the Discussion on Nationalism and Foreign Policy', Problems of Post-Communism, 62, no. 2 (2015), 88-97; Mariya Omelicheva, 'Critical Geopolitics on Russian Foreign Policy: Uncovering the Imagery of Moscow's International Relations', International Politics, 53 no. 6 (2016), 708-726; Magdalena Leichtova, 'Why Crimea was Always Ours: Legitimacy Building in Russia in the Wake of the Crisis in Ukraine and the Annexation of 
identity discourse, Teper argued that the goal was to reunify the Russian nation and, in this light, the main legitimization for annexation of Crimea was 'the realization of bilateral popular will.' ${ }^{15}$ The official discourse had become more nationalist rather than statist, but Vladimir Putin's rhetoric nevertheless denied imperial ambitions. ${ }^{16}$ Biersack and Lear for their part argued that annexation of Crimea was justified by three main narratives: that Crimea historically and culturally belonged to Russia, the need to protect Russian-speakers or Russians in Crimea against "fascist junta" in Kiev, and the Crimeans' right to self-determination. ${ }^{17}$ Becker, Cohen, Kushi, and McManus distinguish between three different kinds of normative discourse to justify annexation: nationalistic view of uniting Russian-speakers, the geopolitical need to resist NATO and EU enlargements, and the liberal concepts of responsibility to protect and right to self-determination. ${ }^{18}$ Yet, they do not think that any of them was the real reason for the annexation of Crimea. They claim that the Kremlin was not sincere in its normative rhetoric but instead driven by national interests and the traditional realist motivations of security through increased state capabilities. Biersack and Lear also argue that strategic objectives of the "status of the Black Sea Fleet and the energy geopolitics in the Black Sea were more obvious motivations than norms".19

Our aim here is not to compare Russian justifications for border changes to other alleged reasons for the annexation. Rather we want to examine the discursive background of these justifications, their coherence and compatibility. The question is not whether the justifications were in line with existing international law - as most clearly they were not ${ }^{20}$ or whether the facts given

Crimea', Russian Politics, 1 no. 2 (2016), 291-315; Gerard Toal, Near Abroad: Putin, the West and the Contest over Ukraine and the Caucasus (Oxford: Oxford University Press, 2017); Paul B. Richardson, 'Geopolitical Cultures, Pragmatic Patriotism, and Russia's Disputed Islands', Eurasian Geography and Economics, 59 no. 1 (2018), 7-27.

15 Yuri Teper, 'Official Russian Identity Discourse in Light of the Annexation of Crimea: National or Imperial?', Post-Soviet Affairs, 32 no. 4 (2015), 378-396.

16 See also, Andrei Tsygankov, 'Vladimir Putin's Last Stand: the Sources of Russia's Ukraine Policy', Post-Soviet Affairs, 31 no. 4 (2015), 279-303.

17 John Biersack, and Shannon O'Lear, 'The Geopolitics of Russia's Annexation of Crimea: Narratives, Identity, Silences, and Energy', Eurasian Geography and Economics, 55 no. 3 (2014), pp. 247-269.

18 Becker et al, 'Reviving the Russian Empire'.

19 Biersack and O'Lear, 'The Geopolitics of Russia's Annexation of Crimea'.

20 See, for example, William H. Burke-White, 'Crimea and the International Legal Order', Survival 56, no. 4 (2014), 65-80; Thomas Grant, Aggression against Ukraine: International Law (New York: Palgrave Macmillan, 2015); Allison, 'Russia and the post-2014 International Legal Order'; see also Lauri Mälksoo, Russian Approaches to International Law (Oxford: Oxford University Press, 2015). 
in support of these justifications were correct - but about the nature and the evolution of the discourse including its argumentative coherence. ${ }^{21}$ Although discourses on borders may contain many statements related to their purpose and functions, ${ }^{22}$ we focus on normative arguments. Moreover, we try to look at the question of to what extent the Russian discourse on the territorial norms can explain the annexation of Crimea. The causal impact of discourses is a contested issue and cannot be proven directly on the basis of mere congruence. ${ }^{23}$ Yet, we can discern two basic variants of the role of discourses for policy. First is the weak claim that discourses enable political action by making some policy choices thinkable. Second is the claim that policies, in this case annexation of Crimea, are pushed forward, if not determined, by the mainstream discourse. In between these two is the idea that adopted policies need to be compatible with political discourses. ${ }^{24}$

When looking at the Russian discourse concerning the border regime and principles that sustain or challenge it, we focus on the political elite including politicians, diplomats, "political technologists" and other opinion makers. Popular discourses can differ from these and can limit the significance of the elite discourses in practice, ${ }^{25}$ but we will not examine them in any systematic manner here. Instead we have gone through key speeches and interviews of the President, and gathered materials from Russian policy journals dealing with international affairs such as Mezhdunarodnaya zhizn' and Russia in Global Affairs from 1992 to 2015. In addition, we rely on other media sources (newspapers, journals, radio interviews) and have utilized the Integrum database for part of the materials.

We have employed qualitative content analysis as the method of analysis. After preliminary screening of the materials, we distinguished between four

21 On discourses of justification, see e.g. Uriel Abulof and Markus Kornprobst, 'Introduction: The Politics of Public Justification', Contemporary Politics 23, no. 1 (2017), 1-18.

22 See e.g. Vladimir Kolosov, Olga Vendina, Anton Gritsenko, Maria Zotova, Fedor Popov and Alexander Sebentsov, 'Looking East and West: the Shifting Concepts of Russia's Borders with CIs Countries and the EU', in Jussi Laine, Ilkka Liikanen and James W. Scott (eds) Post-Cold War Borders Reframing Political Space in Eastern Europe (Abingdon: Routledge 2019), 72-90.

23 Benjamin Banta, 'Analysing Discourse as a Causal Mechanism', European Journal of International Relations, 19 no. 2 (2012), 379-402.

24 See Ole Waever, 'Identity, Communities and Foreign Policy: Discourse Analysis as Foreign Policy Theory', In Lene Hansen and Ole Waever (eds) European Integration and National Identity: the Challenge of the Nordic States (London: Routledge, 2003), 20-49.

25 Ted Hopf, 'Common-Sense Constructivism and Hegemony in World Politics', International Organization, 67 no. 2 (2013), 317-54. 
main discourses, that of status quo and territorial integrity, and three alternative doctrines: national self-determination, geopolitics and historical rights, and coded the materials accordingly. Different actors may apply each discourse in different contexts, as actors are not tied to one discourse or apply just one. After all, such discourses are analytical constructions, not empirical objects with a truth value. ${ }^{26}$ After reviewing the evolution of the discourse in Russia from the break-up of the Soviet Union to the Crimean annexation and beyond, we answer the question of whether the recent changes in policy can be understood against the background of discursive change. We will start by examining the discourse on status quo and territorial integrity, and then move on to discuss the three challenging doctrines: national self-determination, geopolitics, and historical rights.

\section{Discourse Sustaining Territorial Integrity and Status Quo}

The principles of territorial integrity of sovereign states and the status quo of existing borders independently of their inconsistency have been the cornerstones of the international border regime established and practiced after the Second World War. ${ }^{27}$ They have also been at the core of Russia's view of international borders. Until the recognition of the independence of South Ossetia and Abkhazia in 2008, the Russian political leadership argued strongly for the principle of territorial integrity, both internally and externally. Russia was a status quo country both in terms of regime changes and territorial changes. Indeed, for Boris Yeltsin the key task was to "keep Russia territorially intact rather than enlarge it". ${ }^{28}$ For example, in 1994 Yeltsin abstained from recognizing Crimea's independence and did not agree to establish a union with Russia, as the president of Crimea had suggested. ${ }^{29}$

The territorial integrity principle was vital in particular for Russia's internal use. Soon after the break-up of the Soviet Union, Russia's integrity was challenged by calls for national self-determination by the republics of Tatarstan

26 See e.g. Lene Hansen, Security as Practice: Discourse Analysis and the Bosnian War (London: Routledge 2006) and Kevin Dunn and Iver Neumann, Undertaking Discourse Analysis for Social Research (Ann Arbor: University of Michigan Press, 2016).

27 Mark Zacher, 'The Territorial Integrity Norm: International Boundaries and the Use of Force', International Organization 55, no. 2, 215-250.

28 John O'Loughlin, 'Geopolitical Fantasies and Ordinary Russians: Perception and Reality in the Post-Yeltsin Era', Geopolitics 6, no. 1 (2001), 17-48, here p. 43.

29 See, for example, Alan Ingram, 'Broadening Russia's Borders? The Nationalist Challenge of the Congress of Russian Communities', Political Geography 20, no. 2 (2001), 197-219. 
and Chechnya. The threat of Russia's disintegration was present in the discourse of the political elite throughout the 199os. The need to keep federation subjects as part of the federation was a priority, but due to ideological reasons and the weakness of the state structures, the Kremlin granted various rights to the regions. Power-sharing agreements with Tatarstan, and later Bashkorstan, and Kabardino-Balkariya were signed but a militarized conflict between the federation and Chechnya in 1994-1996 resulted in Chechnya's de facto independence. Hence, Russia strongly defended the norm of territorial integrity particularly because of Chechnya. ${ }^{30}$

During Putin's presidency the idea of decentralized power was replaced by the idea of a power vertical. ${ }^{31}$ Even though separatism continued to be represented as one of the major threats to Russia until the late 2000 s, these problems were less burning after the Second Chechen War, at least from the perspective of the Kremlin. For example, in his address to the Federal Assembly in 2003, Putin declared victory over the issues of separatism. ${ }^{32}$ Furthermore, during his election campaign in 2012 he argued that the problem of separatism "has been largely solved", ${ }^{33}$ but he still warned that manifestations of separatism and nationalism should be absolutely excluded from the political agenda.

In addition to the threat of internal separatism, Russian borders were also questioned from the outside after the break-up of the Soviet Union. Most famously, Japan demanded the return of four Kurile Islands that they regarded as their "Northern Territories". As there was no peace treaty between the Soviet Union and Japan after the end of the Second World War, these demands already existed during Soviet times but they were more forcefully put forward in the 1990s. ${ }^{34}$ Moreover, the borders with some of the former Soviet republics were contested. According to the Code accepted in 1992, the former Soviet

30 Mikulas Fabry, 'The Contemporary Practice of State Recognition: Kosovo, South Ossetia, Abkhazia, and their aftermath', Nationalities Papers 40, no. 5 (2012), 661-676, here p. 669.

31 See, for example, Richard Sakwa, The Crisis of Russian Democracy: the Dual State, Factionalism and the Medvedev Succession (Cambridge: Cambridge University Press, 2011).

Vladimir Putin, 'Poslanie Federal'nomu Sobraniyu Rossiiskoi Federatsii' [Address to the Federal Assembly], (16 March 2003), available at: \{http://archive.kremlin.ru/text/appears/ 2003/05/44623.shtml\}, accessed 31 January 2019.

33 Vladimir Putin, 'Demokratiya i kachestvo gosudarstva' [Democracy and the Quality of the State]. Kommersant, 6 February, available at: \{https://www.kommersant.ru/doc/1866753\}, accessed 31 January 2019.

34 See, Tsuyoshi Hasegawa, The Northern Territories Dispute and Russo-Japanese Relations: Volume 2, Neither War Nor Peace, 1985-1998 (Berkeley, CA: International and Area Studies Publications, University of California at Berkeley, 1998); Hiroshi Kimura, Distant Neighbours. Vol. 2. Japanese-Russian Relations Under Gorbachev and Yeltsin (New York: M.E. Sharpe, 2000). 
administrative borders between Russia and Latvia, Lithuania, and Estonia were taken as state borders until the conclusion of border treaties with these countries. Particularly with Estonia and Latvia, the border treaty negotiations were difficult because these countries had lost strips of their territory to the Russian Soviet Federative Socialist Republic after they had been incorporated into the Soviet Union, and they regarded these annexations as illegal. ${ }^{35}$ Potential historical border issues also existed with regard to the Kaliningrad area and the Karelian Isthmus that had been part of Germany and Finland respectively before the Second World War, but these states did not put forward any territorial claims. Although Germany had denounced its interest for Kaliningrad, some Russians, including even scholars, feared that the threat of secession of Kaliningrad was real and involved 'third parties' 36 and domestic debate over the Karelian question was conducted in Finland. ${ }^{37}$

Moreover, the border with China remained unsettled in some areas, for example, in 2003 Dmitry Trenin mentioned "a hypothetical probability that China may reanimate its territorial claims against Russia". ${ }^{38}$ At the time, the Russian-Chinese border had not been demarcated for the totality of its 4,300 kilometer length. Moreover, many Chinese felt that historically, large parts of Eastern Siberia were ancient Chinese lands. MGimo professor, China expert Aleksandr Lukin denied that China would have any territorial demands to Russia as officially China had not made any such claims. Lukin explained that some Chinese historians had brought up the opinion that Russia had captured many important Chinese territories in the 19th century, but all border questions with China had been solved..$^{39}$ Instead, Russian experts emphasized that China and Russia have common interests in safeguarding the principles of state sovereignty and territorial integrity upon which also Shanghai Cooperation Organisation (SCO) was based. ${ }^{40}$

35 Claes Levinsson, 'The Long Shadow of History: Post-Soviet Border Disputes - The Case of Estonia, Latvia, and Russia, Connections 5, no. 2 (2006), 98-110.

36 Irina Kobrinskaya, 'A Marathon Election Campaign', Russia in Global Affairs, no. 1 (2002), available at: $\{$ http://eng.globalaffairs.ru/number/n_44\}, accessed 31 January 2019.

37 Pertti Joenniemi, 'The Karelian Question: On the Transformation of a Border Dispute', Cooperation and Conflict 33, no. 2 (1998), 183-206.

38 Dmitry Trenin, 'Euro-Pacific Nation', Russia in Global Affairs, no. 1 (2003), available at: \{http://eng.globalaffairs.ru/number/n_639\} accessed 31 January 2019.

39 Aleksandr Lukin, 'Rossiisko-kitaiskie otnosheniya: ne oslablyat' usilii' [Russian-Chinese relations: don't ease off], Mezhdunarodnaya zhizn' (3o November 2009).

40 Aleksandr Lukin, 'Rossiya-Kitai' [Russia-China], Mezhdunarodnaya zhizn' (26 December 2001); Mikhail Titarenko, 'Rossiya, Kitai, Indiya v global'nom mire' [Russia, China and India in the global world], Mezhdunarodnaya zhizn' (28 June 2002). 
Russia resisted actual and potential territorial claims with status quo rhetoric. Russian representatives held that border changes were not possible because of overall stability. Because all border adjustments are connected with wars, Yeltsin argued, even smaller ones would cause chaos in the whole of Europe. ${ }^{41}$ In Putin's view "changing borders is not the best way to resolve problems", but instead he preferred "integration and cooperation". ${ }^{42}$ For the Russian leaders, mere domestic debate over territorial issues in the neighboring countries threatened stability and good neighborly relations: for example, in 1997 Yeltsin stated in a press conference in conjunction with the meeting with the President of Finland: "I urge Finnish journalists in particular: take away the territorial issue from your newspapers and television". ${ }^{43}$ With regard to Japan, Russia however was ready to negotiate and willing to return the two smallest of the four disputed islands in exchange for a peace treaty, but this was, in fact, the position of the Soviet Union already in the 1950s. Border treaties with Latvia and Estonia were only signed when (even symbolic) reference to the pre-war borders was dropped. When these countries talked about restoring their prewar borders, Russians accused them for being irresponsible and obstinate.

As far as the territorial integrity of the post-Soviet states was concerned, Russia's official discourse sustained the status quo. With regard to Georgia, until 2008 Russia's position echoed Evgenii Primakov's ideas that Russia should try to build better relations with Georgia by recognizing its territorial integrity. ${ }^{44}$ Putin also emphasized that "we proceed from the thesis of territorial integrity of Georgia". ${ }^{45}$ Dmitri Medvedev contended in May 2008 that "we must

41 Ruslan Ignatyev, 'Chuzhoj zemli my ne hotim ni pyadi, No i svoej vershka ne otdadim' [We Do not want others' land but shall not give an inch of ours], Rossiiskaya Gazeta (14 April 1994).

42 Vladimir Putin, 'Zayavlenie dlya pressy i otvety na voprosy na sovmestnoi press-konferentsii s Prezidentom Finlyandii Tar'ei Halonen' [Press Release and Answers to the Questions at the Press Conference together with Tarja Halonen, President of Finland], (3 September 2001), available at: $\left\{\mathrm{http}: / /\right.$ kremlin.ru/events/president/transcripts/21319\}, accessed $3^{1}$ January 2019.

43 Boris Yeltsin, cited in Kalle Koponen, 'Jeltsin: Venäjä ei luovuta Karjalaa [Yeltsin: Russia Does not Cede Karelia]', Helsingin Sanomat (28 November 1997), available at: \{http:// www.hs.fi/kotimaa/art-2000003678453.html\}, accessed 31 January 2019.

Yevgeni Primakov, 'V proshedshem godu proyavilsya pozitivnyi kharakter kursa rukovodstva Rossii' [In the Last Year a Positive Nature of the Russian Leadership's Course Has Manifested], Mezhdunarodnaya zhizn' (6 February 2004).

45 Vladimir Putin, 'Nesmotrya na kataklizmy, 2004 god zakonchilsya v tselom so znakom plyus' [Despite the cataclysms, 2004 has ended with a plus sign in general], Mezhdunarodnaya zhizn' (28 January 2005). 
have an extremely serious approach to any attempt ... to meddle into other countries' affairs, and attempts to redraw their borders". 46

Ukraine's territorial integrity, too, was not officially contested. As diplomat Valerii Musatov stated in 1999, "Russia had recognized territorial integrity of Ukraine and its borders in the 1990 Agreement and again confirmed this in the Accord of the establishment of the CIS in December 1991". ${ }^{47}$ The ratification of the Treaty on Friendship, Cooperation and Partnership between the Russian Federation and Ukraine was pushed by the government, and by Yevgeny Primakov in particular. The politicians, such the Moscow mayor Yurii Luzhkov, the well-known nationalist Sergei Baburin and members of the Liberal Democratic Party, who were demanding Crimea's "reunification with Russia" or resisted the ratification of the treaty on the basis that it "would fix the position of Crimea as belonging to Ukraine" were labelled as "ethnic nationalists and part of the neo-imperialist group". 48

The principle of territorial integrity was also defended on the instrumental grounds. Yekaterina Kuznetsova argued that "helping post-Soviet states to restore their integrity would bring Russia more dividends than the hopeless and costly support for the unrecognized autonomies". ${ }^{49}$ Similarly, publicist Leonid Radzikhovsky, who later criticized the annexation of Crimea, argued that "gaining new territories is precisely the thing that Russia does not need these days. - To support foreign separatism means to throw stones at your neighbors while living in a glass house." 50

Although the need to unite the Russian World (Русский мир) beyond the current state borders was officially adopted in the mid-20oos, it did not directly contradict the principle of territorial integrity of other states. In his 2005 address, Putin famously used the much-cited formulation "the collapse of the Soviet Union was the greatest geopolitical catastrophe of the century"51

46 Dmitri Medvedev, Speech at the Military Parade marking the 63rd Anniversary of Victory in the Great Patriotic War, (9 May 2008), available at: \{http://en.kremlin.ru/events/president/ transcripts/30\}, accessed 31 January 2019.

47 Valerij Musatov, 'Neprostaya sud'ba dogovora s Ukrainoj' [Difficult Fate of the Treaty with Ukraine], Mezhdunarodnaya zhizn', 2 (1 February 1999).

48 Igor Zevelev, 'The Russian World Boundaries'.

49 Yekaterina Kuznetsova, 'The Near Abroad: Increasingly Far Away from Russia', Russia in Global Affairs, no. 1 (2005), available at: $\{$ http://eng.globalaffairs.ru/number/n_4411\}, accessed 31 January 2019.

50 Leonid Radzikhovsky, 'Georgiophobia', Russia in Global Affairs, no. 4 (2004), available at: $\{\mathrm{http} / /$ eng.globalaffairs.ru/number/n_3879\}, accessed 31 January 2019.

51 Vladimir Putin, 'Poslanie Federal'nomu Sobraniyu Rossiiskoi Federatsii' [Address to the Federal Assembly], (25 April 2005), available at: \{http://kremlin.ru/events/president/ 
but this can hardly be interpreted as a new doctrine. For example, with regard to Crimea, the argument was made that it should and could be kept ... "as part of the Russian world" even without "reunification".52 Crimea's "long return to home" would not mean annexation but civilizational integration, "return to one's historical and cultural roots". ${ }^{53}$ Yet, this presupposed Ukraine joining the Customs Union and the Eurasian Economic Union. Russian politicians stressed, as did the then Duma Deputy Konstantin Kosachev, that Russia, "must clearly show to its partners that, for example, no one in Russia is going to reclaim the Crimea from Ukraine, but at the same time, that Moscow's concern about the status of the Russian language in Ukraine or in the Baltic States has, not imperial, but natural grounds, as is the case with any Western country". ${ }^{4}$

Dissatisfaction with the Russian Federation's existing borders was prevalent within communist and nationalist groups ever since the disintegration of the Soviet Union. The communists and nationalists did not recognize the Russian Federation as real Russia: it was a stump which hungered the revival in its former borders or at least those of 'Slavic nations. ${ }^{55}$ The revision of borders was in the agenda of the communist opposition already in the early 199os and it was supposed to happen by voluntarily re-establishing a Eurasian or Slavic union state (soyuznoe gosudarstvo).

There were, indeed, elements in the Russian discourse hinting that territorial integrity would not apply to all post-Soviet states, because there were different levels of sovereignty. ${ }^{56}$ In particular, the former Soviet republics would not have full sovereignty over their former autonomous areas. ${ }^{57}$ For example, MGIMo professor, Andranik Migranyan argued that "Azerbaijan, Moldova,

transcripts/22931\}, accessed 31 January 2019. See also, Mikhail Suslov, "Russian World" Concept: Post-Soviet Geopolitical Ideology and the Logic of "Spheres of Influence", Geopolitics 20, no. 2 (2018), 330-353.

$5^{2}$ Aleksandr Mashchenko, 'Krymskaya odisseya' [Crimean Odyssey], Mezhdunarodnaya zhizn', no. 5 (31 May 2013).

53 Ibid.

54 Konstantin Kosachev, 'Three Birds with One Stone?', Russia in Global Affairs, no. 1 (2011), available at: \{http://eng.globalaffairs.ru/number/Three-Birds-with-One-Stone-15146\}, accessed 31 January 2019.

55 On different understandings of Russian identity in the 1990s - Soviet, ethno-nationalist etc. see Vera Tolz, 'Forging the nation: National identity and nation building in postcommunist Russia', Europe-Asia Studies, 50 no. 6 (1998), 993-1022.

56 Ruth Deyermond, 'The Uses of Sovereignty in Twenty-first Century Russian Foreign Policy', Europe-Asia Studies, 68 no. 6 (2016), 957-984.

57 Alexander Aksenyonok, 'Self-Determination: Between Law and Politics', Russia in Global Affairs, 1 (2007), available at: \{http://eng.globalaffairs.ru/number/n_7979\} accessed 31 January 2019; Sergey Markedonov, 'Unrecognized Geopolitics', Russia in Global Affairs, 
Ukraine or Georgia [did not have] a legitimate right to govern their secessionist territories - annexed to the master republics by Stalin's personal wish and obstinacy. - Abkhazia and South Ossetia had positioned themselves outside the Georgian state even before the break-up of the Soviet Union."58

In general, however, Russia firmly represented itself as the safeguard of the "Westphalian system", and regarded the West as the destroyer of the international order. A case in point was Kosovo. Even though Serb atrocities were recognized by Russian politicians, human rights violations were not something that would justify secession. ${ }^{59}$ The Foreign Policy Concept of 2008 criticized "some states that try to revise norms of international law in universal documents such as the UN Charter, Declaration of principles of international law, and the Final Act of OSCE from 1975" ${ }^{60}$ The recognition of Kosovo's independence was seen as "a manifestation of deep global tendency of gradual destruction of the order that formed after the WWII on the principles of sovereignty and territorial integrity of states and on actual ban on secessions". ${ }^{11}$ For example, CPRF leader Zyuganov warned about a domino effect in the case of recognizing independence of Kosovo: it would lead to demands for independence of Catalonia, Basque land, Northern Ireland, Corsica, the collapse of the Belgian federation and new disputes in the Balkans, "and this means new wars". ${ }^{2}$ Similar warnings of a domino effects or mine fields were issued by many, for example Vladimir Lukin from Yabloko, for whom giving the right to national self-determination to all national entities "would lead to hell, to the self-destruction of the world". ${ }^{33}$ Aleksei Arbatov predicted that Kosovo's

no. 1 (2006), available at: $\{$ http://eng.globalaffairs.ru/number/n_6186\}, accessed 31 January 2019.

58 Andranik Migranyan, 'Georgia Propelling Its Disintegration', Russia in Global Affairs, no. 4 (2004), available at: $\{\mathrm{http}: / /$ eng.globalaffairs.ru/number/n_3878\}, accessed 31 January 2019.

59 For example, Iurii Luzhkov, 'Vospominaniya o budushchem' [Memories of the future], Izvestiya (23 March 2001); Aleksei Arbatov, 'NATO - glavnaia problema dlia evropeiskoi bezopasnosti' [NATO - the main problem for the European security], Nezavisimaia gazeta (16 April 1999).

6o The Foreign Policy Concept of the Russian Federation, (12 July 2008), available at: \{http:// en.kremlin.ru/supplement/4116\}, accessed 31 January 2019.

61 Dmitrii Furman, "'Parad suverenitetov" v peredele mira' [Parade of the Sovereignties in the Redivision of the World], Mezhdunarodnaya zhizn', no. 5 (2008).

62 Cited in Sergei Obukhov 'Dve Bolgarii. Gennadii Zyuganov: Rano spisyvat Rossiyu so schetov', Sovetskaya Rossiya (24 October 2000).

63 Vladimir Lukin, 'Groznye razdumiya, Natsionalnoe samoopredelenie - vernyi put k samounichtozheniyu' [Bodeful thoughts, National self-determination - the right way to self-destruction], Segodnya (17 February 1995). 
secession from Serbia "may provoke similar processes in Abkhazia, South Ossetia, and Transdniestria". 64

The principles of territorial integrity and status quo were rather consistently supported by the Russia's political elite also in other international crises. ${ }^{65}$ They accused the West of "double standards" and deplored that the idea of sovereignty and territorial integrity ceased to be axiomatic. ${ }^{66}$ However, some hinted that Russia might also apply the principle of national self-determination where it deems it applicable because it could not just be a passive bystander. ${ }^{67}$

Even after the Georgian War and the recognition of South Ossetia and Abkhazia, Russian leadership defended the principle of state sovereignty and status quo of borders. The Medvedev treaty proposal on European Security did not contain any new elements regarding the territorial regime, instead it was "guided by the principles set forth in the Charter of the United Nations and the Helsinki Final Act of the Conference for Security and Cooperation in Europe". Indeed, Sergey Karaganov argued that, "The future treaty must reiterate the provisions of the Helsinki Final Act on the inviolability of the borders in order to prevent the further fragmentation of states or their reunification with the use of force. Kosovo, South Ossetia, and Abkhazia must become the last states that broke away through force. This 'Pandora's box' must be shut, at least in Europe." 68

In sum, the principles sustaining status quo, the territorial integrity of sovereign states and inviolability of borders, have been at the core of Russian discourse since the dissolution of the Soviet Union. Although there were

64 Alexei Arbatov, 'Is a New Cold War Imminent?' Russia in Global Affairs, no. 3 (2007), available at: $\{$ http://eng.globalaffairs.ru/number/n_9127\}, accessed 31 January 2019.

65 See, for example, Iurii Luzhkov, 'Ne sprashivai, po kom zvonit kolokol' [Don't ask for whom the bell tolls], Izvestiya (13 July 2001b); also, Aleksei Arbatov, 'NATO - glavnaia problema dlia evropeiskoi bezopasnosti' [NATO - the main problem for the European security], Nezavisimaia gazeta (16 April 1999); Grigori Yavlinsky, 'Ne vtiagivaite Rossiyu v voinu!' [Don't drag Russia into the war!], Literaturnaya gazeta (31 March 1999).

66 Sergey Karaganov, 'The Chances and Challenges of the New World', Russia in Global Affairs, no. 2 (2003), available at: \{http://eng.globalaffairs.ru/number/n_845\}, accessed 31 January 2019.

67 Konstantin Kosachev, 'Proshlogodnie raskaty slyshny v 2004' [The last-year's peals are heard in 2004], Mezhdunarodnaya zhizn' (16 January 2004), (Kosachev as a participant to a discussion here).

68 Sergei Karaganov, 'The Magic Numbers of 2009', Russia in Global Affairs, no. 2 (2009), available at: $\{$ http://eng.globalaffairs.ru/number/n_13036\}, accessed 31 January 2019. 
instrumental, internal reasons for this doctrine, ${ }^{69}$ it was not abandoned after the Chechen problem was stabilized. Yet, alternative discourses of borders also existed that either denied the full sovereignty and thereby territorial integrity of the former Soviet republics or lent support to principles that justified territorial changes. Next, we will examine the discursive evolution of three such principles: national self-determination, geopolitics, and historical rights.

\section{4}

\section{National Self-determination}

Self-determination is a liberal doctrine that starts from the principle of selfgovernance. The idea of national self-determination is however a contested doctrine. There are two basic variants: firstly, the view that there is a preexisting nation that should be united in order to resort to self-determination, and secondly the view that individuals can express their own will, for example, in a referendum with regard to the community to which they belong, and thus exercise national self-determination according to the views of the majority. Moreover, there are two views with regard to when self-determination as a justification for secession: as a remedial right only when the population has been oppressed by the patron state or as a positive right even in the absence of political oppression. ${ }^{70}$

Self-determination has a long pedigree in the Russian discourse since the doctrine had already been part of Lenin's policy at the time of the Russian revolution. ${ }^{71}$ During the Soviet era, it was mostly related to various degrees of autonomy granted to the territorial units on the basis of their nationhood. This then led to the basic justification of the dissolution of the Soviet Union. In the 1990s, there were politicians among the Russian elite who expressed general arguments in favour of further application of the principle of national selfdetermination. In the context of Chechen conflicts and in particular during the first Chechen War, these politicians tried to justify national self-determination as the will of the people, framing it as part of democracy discourse. Another

69 Igor Zevelev, 'Russia's Policy Toward Compatriots in the Former Soviet Union', Russia in Global Affairs no. 1 (2008), available at: \{http://eng.globalaffairs.ru/number/n_10351\}, accessed 31 January 2019.

70 See e.g. Margaret Moore, National Self-Determination and Secession (Oxford: Oxford University Press 1998).

71 V.I. Lenin, Critical Remarks on the National Question: The Right of Nations to SelfDetermination (Moscow: Foreign Languages Publishing House, 1954 [1914]). 
section of the elite was focusing on national self-determination not as a general right, but only in terms of the rights of Russians in the former Soviet Union.

In the course of 1990s, support for self-determination declined rapidly. Those speaking on behalf of national self-determination as a general principle could be found, for example, in the Yabloko party. Grigorii Yavlinsky, the then leader of Yabloko, argued that territorial integrity was no higher value than the right of people to decide themselves what they wanted. He warned about consequences of forcing people to be Russian citizens; “...it would not become a republic inside Russia [ $v$ sostave Rossii], but a concentration camp inside Russia. Of course, Russia can occupy this territory, but like that it cannot make people think in a different way." ${ }^{72}$

Compared to the 1990s, the voices speaking on behalf of a generic principle of national self-determination were virtually absent in the Putin era. Only some pundits contended that Russia could voluntarily let some of its territories go, as Britain had released its colonies. ${ }^{73}$ Applying the right to entities, such as Chechnya, was rejected, because it could work as a catalyst for a domino effect. The [Marxist] "formula of 'self-determination until secession' has gone out of date". ${ }^{74}$ Yet, the ethno-nationalist program for restoration of geographical congruence between the state and the nation, advocating the creation of a new political entity of ethnic Russians and some East Slavs by reunifying Russia, Belarus, part of Ukraine, and northern Kazakhstan, was often discussed as an option and backed by the principle of self-determination. Aleksandr Tsipko for example asked "Why divided Germans had the right to re-unification but divided in 1991, Russians, Ukrainians and Belarussians do not?"75 There were several attempts from 1998 to 2001 to embody such ideas in legislative initiatives, but none of them was adopted. ${ }^{76}$

The key tendency was however the increasing concern for Russians and Russian speakers living in the former Soviet states. Karaganov argued that

72 Grigori Yavlinsky, 'Vlast b'etsia v konvulsiiakh samopoedaniia. Lider "Iabloka” kritikuet vsekh i po vsem azimutam' [The authority is convulsing in self-abuse. The Leader of 'Yabloko' critizes everyone on all azimuths], Nezavisimaia gazeta (16 October 1996).

73 Vladislav Inozemtsev, 'Colonies vs. Dependencies: An Invitation to a Discourse', Russia in Global Affairs no. 2 (2013), available at: \{http://eng.globalaffairs.ru/number/Vladimir -Putins-Fourth-Vector---16048\}, accessed 31 January 2019.

74 Yevgeni Primakov, 'Voina s islamom mozhet raskolot Rossiiu' [A war with Islam may split Russia], Izvestiya (5 November 2002).

75 Aleksandr Tsipko, 'Argumenty v zashchity rossiiskogo suvereniteta' [Arguments for the Russian Sovereignty], Mezhdunarodnaya zhizn' (15 August 2003).

76 Igor Zevelev, 'Russia's Future: Nation or Civilization?', Russia in Global Affairs, no. 4 (2009), available at: \{http://eng.globalaffairs.ru/number/n_14246\}, accessed 31 January 2019. 
neither a neo-imperialist policy of re-establishing the Soviet empire, nor a policy aimed at strengthening the statehood of the "newly independent republics" are feasible. ${ }^{77}$ Russia should therefore try to find out a third way between the two: the county should play an active post-imperial role in creating a confederation. In this context, Karaganov regarded the Russian speakers in the former Soviet States as an important asset in exercising influence. The idea that Russia has special rights in protecting ethnic Russians or Russia-speakers was labelled the "Karaganov doctrine". This doctrine did not, however, directly imply territorial changes but was seen as being in line with what Russians regarded as widely shared principles of minority rights. ${ }^{78}$ However, Russian peace-keeping operations in the area of the former Soviet Union were already then seen to prove that the principle of status quo was wishful thinking. ${ }^{79}$ The argument that the principles of territorial integrity and the inviolability of borders should not have been followed so mechanistically when the USSR was dissolved was also articulated in Kozyrev's famous mock speech at the CSCE foreign ministers meeting in December 1992. ${ }^{80}$

This view stressing self-determination of ethnic Russians continued to be expressed in the 200os. For example, Sergei Kortunov argued that there should have been negotiation processes on disputed territories and borders, and that the question of national self-determination should have been brought up accordingly. ${ }^{81}$ Vladimir Degoyev also wrote that bringing the process of the Soviet Union's disintegration to a logical end would entail "international recognition of the right to self-determination for those peoples living in the post-Soviet area, including those willing to be incorporated into Russia". ${ }^{82}$ Yet, overall there was little support for the recognition of these entities as independent states.

In the case of Kosovo, Russia's position was that secession is possible but only if the very existence of the people in question is threatened: 'outside the

77 Sergey Karaganov, 'On Russia focused people interest defending issues in "close borderlands"', Diplomaticheskii Vestnik, 21-22 (15-30 November 1992).

78 See also, The Foreign Policy Concept (18 February 2013), available at: \{http://www.mid .ru/en/foreign_policy/official_documents/-/asset_publisher/CptICkB6BZ29/content/ id/122186\}, accessed 31 January 2019.

79 Pavel Baev, 'Peace-Keeping as a Challenge to European Borders', Security Dialogue, 24 no. 2 (1993), 137-150.

$80 \quad$ Andrei Kozyrev, 'Speech at the CSCE meeting', Stockholm (14 December 1992).

81 Sergei Kortunov, 'Natsional'naya identichnost' 'Rossii: vneshnepoliticheskoe izmerenie', Mezhdunarodnaya zhizn' (6 June 2003).

82 Vladimir Degoyev, 'Wider Europe's Horizons in the Caucasus', Russia in Global Affairs, no. 4 (2004), available at: $\{\mathrm{http}: / /$ eng.globalaffairs.ru/number/n_3886\}, accessed 31 January 2019. 
colonial context, international law allows for secession of a part of a State against the latter's will only as a matter of self-determination of peoples, and only in extreme circumstances, when the people concerned is continuously subjected to most severe forms of oppression that endangers the very existence of the people'.83 In August 2008, Russia nonetheless decided to recognize the independence of South Ossetia and Abkhazia "considering the freely expressed will of the Ossetian and Abkhaz peoples", which was seen as obvious tit-for-tat for the Western recognition of Kosovo. ${ }^{84}$ By and large, the justifications used by Russia mimicked those of the Western recognition of Kosovo. ${ }^{85}$ Indeed, Medvedev defended the policy of recognition by saying that "you cannot have one rule for some and another rule for others". ${ }^{86}$ Moreover, it was claimed that "Russia remained committed to the principle of a country's territorial integrity to the very end" but due to the "mass killings of Russian citizens" and the recognition of Kosovo by the West, it was forced to recognize the independence of the territories where "the metropolitan nation had committed acts of unjustifiable cruelty". ${ }^{87}$ That can be seen as a reason why no recognition of Transniestria or Nagorno-Karabakh followed. In any case, Russia still did not recognize the independence of Kosovo. The recognition of South Ossetia and Abkhazia was hence not a complete turning point in the Russian discourse, although the inconsistency of Russia's policy of recognition was noted also in the Russian debate. ${ }^{88}$

Self-determination played a key role in Russia's argumentation justifying the annexation of Crimea. In the view of Putin, the residents of Crimea exercised their right of self-determination: "First of all there was a need to help to create conditions for peaceful, free will-expressing (volition), so that the Crimeans

83 'Written Statement of the Russian Federation', International Court of Justice, 16 April 2009, 39-40, available at $\{$ https://www.icj-cij.org/en/case/141/written-proceedings\}, accessed 31 January 2019.

84 Mikulas Fabry, 'The Contemporary Practice of State Recognition: Kosovo, South Ossetia, Abkhazia, and their aftermath', Nationalities Papers, 40 no. 5 (2012), 661-676, here p. 661.

85 Bruno Coppieters, 'Conflict resolution after the 2008 Georgia-Russia War: the Taiwan and Kosovo models as tools for mobilization and comparison', Nationalities Papers, 40 no. 5 (2012), 677-701, here p. 667.

86 Quoted in ibid, 680.

87 Ivan Kotlyarov, 'The Logic of South Ossetia Conflict', Russia in Global Affairs, 4 (2008), available at: \{http://eng.globalaffairs.ru/number/n_11891\} accessed 31 January 2019.

88 Alexander Buzgalin and Andrei Kolganov, 'The Caucasian War and Public Interest', Russia in Global Affairs, no. 4 (2008), available at: \{http://eng.globalaffairs.ru/number/n_1189o\}, accessed 31 January 2019. 
could themselves determine their fate for the first time in history". ${ }^{89}$ Medvedev resorted to historical parallels of national self-determination leading to unification, as the "re-integration of Crimea" was in his view comparable to the fall of the Berlin Wall and unification of Germany, or return of Hong Kong and Macao to mainland China..$^{90}$ The same argumentative logic was partly applied for the separatists' cause in South Eastern Ukraine.

To the extent self-determination was accepted as a valid reason for secession, Russian leaders regarded it as a remedial right only. ${ }^{91}$ Interestingly, in December 2013 Putin had argued that Crimea on the one hand and South Ossetia and Abkhazia on the other should not be compared with each other, because in South Ossetia and Abkhazia it was a question of wide, bloody, interethnic conflict. Moreover, attacks on Russian peacekeepers was the primary cause of the war there. "In Crimea there is nothing like that and I hope there will not be. We have a contract of keeping our fleet there. It is a stabilizing factor of international and regional politics". ${ }^{92}$ Accordingly, in the Crimean case, it was then stressed that suppression justified secession: the Ukrainian revolution was to be blamed for the change of Russia's policy. Had the "special language regime" and autonomy continued, Russia would not have seen the need for reunification. But "now things looked different: nationalists who came to power in Kyiv, the repeal of the law on languages, and, the most importantly, the uncertain legitimacy of the central government."93 "Russia had never said that Crimea should become part of Russia. - But Kyiv is not ready for cooperation or dialogue, and this is the central issue." 94

89 Vladimir Putin, 'Obrashchenie Prezidenta Rossiiskoi Federatsii' [Address by President of the Russian Federation],(18March 2014), available at: \{http://kremlin.ru/events/president/ news/20603\}, accessed 31 January 2019.

9o Dmitri Medvedev, 'Otchet Pravitel'stva o rezul'tatakh raboty v 2014 godu' [Government report on its performance in 2014], (21 April 2015).

91 Tero Lundstedt, 'The Changing nature of the Contemporary Russian Interpretation of the Right to Self-Determination under International law', in P. Sean Morris (ed.), Russian Discourses on International Law: Sociological and Philosophical Phenomenon (New York: Routledge, 2019), 197-219.

92 Vladimir Putin, 'Press-konferentsiya Vladimira Putina' [News conference of Vladimir Putin] (19 December 2013), available at: $\{$ http://kremlin.ru/events/president/news/19859\}, accessed 31 January 2019.

93 Vladimir Bruter, 'Failing Again - But Better than before', Russia in Global Affairs, no. 1 (2014), available at: \{http://eng.globalaffairs.ru/number/Failing-Again-But-Better-Than-Before $-16497\}$, accessed 31 January 2019.

Ibid. 
There were only few who publicly criticized the annexation of Crimea in Russia. These critics did not, however, deny the principle of self-determination as such but emphasized that it violated the principle of territorial integrity and inviolability of borders. For example, Yabloko, albeit without any broader support in Russian society, regarded the annexation of Crimea as a violation of international law and the UN Charter. ${ }^{95}$ Yabloko represented itself as "in opposition to aggressive neo-imperial course of Vladimir Putin". 96

Russia's policy towards national self-determination did not manifest itself as a new doctrine in favour of secession in international crises and issues of separatism. Although many Russians who are seen as pro-Kremlin voices supported the drive for Scottish independence, underlining the parallels with the Crimean case, ${ }^{97}$ Putin himself stated before the annexation of Crimea that Scottish independence is a domestic matter for Britain. In his view, European integration makes claims for self-determination more acceptable, but he added that "one should not forget that being part of a single, strong state has some advantages and one should not overlook this." 98 Similar kind of argumentation can be found with regard to the Catalan issue. In February 2006 Putin argued that Catalan decisions and Spanish authorities' reaction to them is an internal affair of Spain. ${ }^{99} \mathrm{He}$ further discussed the benefits of powerful unions (moshchnie, bolshie obedineniya) in the era of globalization and competition, but also recognized the right of smaller peoples and ethnic groups to their cultural and

95 Yabloko, 'Neoimperskii kurs vedet k katastrofe'. Zayavlenie RODP "YAвLOKO" [Neo-imperial course leads to the disaster. Statement of the RUDP "YABLOKO"], (19 March 2014).

96 Ibid, see also, for example, Boris Vishnevsky, 'Pomoshch podzhigatelei pogorel'tsam' [Arsonists' help to the fire vitims], Yabloko (12 August 2014), available at: \{http://spb.yabloko. ru/node/3022\}, accessed 31 January 2019; Sergei Mitrokhin, 'Tsena otzhima Kryma' [The price of grabbing Crimea], Interview in Radio Svoboda by Mikhail Sokolov (21 March 2016), available at: $\{$ http://www.yabloko.ru/publikatsii/2016/o3/21_2\}, accessed 31 January 2019; Sergei Mitrokhin, "Yabloko" khochet v Dumu!' [Yabloko wants to get into the State Duma], Interview in Radio Svoboda (6 July 2016), available at: \{http://www.yabloko.ru/ publikatsii/2016/07/06_1\}, accessed 31 January 2019.

97 Tom Parfitt, 'Pro-Kremlin bloggers throw weight behind Scottish independence', Daily Telegraph (1o September 2014), available at: \{http://www.telegraph.co.uk/news/worldnews/ europe/russia/11087449/Pro-Kremlin-bloggers-throw-weight-behind-Scottish -independence.html\}, accessed 31 January 2019.

98 'Scottish independence: Vladimir Putin says referendum "a domestic issue", ввс News (19 January 2014), available at: \{http://www.bbc.com/news/uk-scotland-scotland-politics $-25800441\}$, accessed 31 January 2019.

99 Vladimir Putin, 'Interv'yu ispanskim sredstvam massovoi informatsii' [Interview to the Spanish Media], (7 February 2006), available at: \{http://kremlin.ru/events/president/ transcripts/23419\}, accessed 31 January 2019. 
national identity that could be preserved by creating autonomy. In September 2017 , Russian reactions to the independence referendum in Catalonia consistently regarded the issue Spain's own domestic affair that should be resolved on the basis of Spanish law. ${ }^{100}$ The key target of criticism was, not surprisingly, the Western hypocritical attitude and double standards in the issue compared to Crimea or Kosovo.

While Russian leaders have refrained from lending any direct support to separatism in the West, there have been allegations of backing these movements. There was, for example, a strange meeting titled 'A dialogue of nations: Peoples' right to self-determination and the building of a multi-polar world,' of Western separatist movements that was held in Moscow in September 2015. The meeting was organized by an anti-globalization movement that lacked any official status but was reportedly backed by the Kremlin. ${ }^{101}$

In sum, although Russia relied on the precedent of Kosovo in the cases of South Ossetia, Abkhazia, and Crimea, there was not a strong discourse advocating self-determination as a general principle nor did Russia recognize Kosovo for that matter. Even in the case of Crimea, it was seen not as a positive but a remedial right under oppression. National self-determination has thus been part of Russian discourse of borders, but it has mostly concerned the rights of Russians or Russian speakers or other proxy groups, as part of Russia's compatriot policy.

\section{Geopolitical Justifications}

Any argument dealing with borders and territories can be seen as "geopolitical" but two geopolitical arguments with regard to justifying border changes can be seen at the core of traditional geopolitical thinking: the idea of natural borders, such as mountains, deserts, oceans or rivers, and the idea that great powers should be able and have a moral right to expand their borders. When Astrov and Morozova claim that geopolitics held a privileged position

100 For example, Maria Zakharova, 'Briefing by Foreign Ministry Spokesperson Maria Zakharova', Moscow (28 September 2017), available at: $\{\mathrm{http} / /$ www.mid.ru/en/web/guest/foreign _policy/news/-/asset_publisher/cKNonkJEo2Bw/content/id/2879203\#0\}, accessed 31 January 2019.

101 'Russian "Anti-Globalization" Movement to Unite Separatists From Western Countries', The Moscow Times Online (16 September 2015), available at: $\{$ https://themoscowtimes .com/news/russian-anti-globalization-movement-to-unite-separatists-from-western -countries-49589\}, accessed 31 January 2019. 
throughout the 199os but was diminishing during the Putin era in the 2000s, it does not necessarily mean that there was an articulated geopolitical doctrine with regard to Russia's borders and the territorial regime in general. ${ }^{102}$ Part of the problem is that geopolitics is often represented as a deterministic force rather than as a political doctrine that would be in need of any justification.

The idea of natural borders is notoriously ambivalent especially in the case of Russia, because, as often noted, Russia lacks natural borders apart from the Arctic Sea in the North and the Pacific Ocean in the East. Vladimir Zhirinovsky and the Liberal Democrats have argued for the territorial expansion of Russia on the basis of returning the natural borders, but here natural borders were mainly conceived historically either in the extent of the Soviet Union or sometimes the czarist Russia, including Finland and parts of Poland, or comprising the Russian Orthodox world. Sometimes "natural borders" extends to new areas, as a natural growth of the great power. In his autobiography, The Final Thrust to the South, Zhirinovsky argued for a division of the world by the great powers that would allow Russia to acquire Iran, Turkey, and Afghanistan. Russian soldiers, he wrote, would "wash their boots in the warm water of the Indian Ocean."103

Russia's decision to annex the Crimean peninsula and the support to separatist in the Eastern Ukraine has been, however, most often associated with Alexander Dugin's geopolitical neo-Eurasianist thinking. Barbashin and Thoburn, for example, named Dugin as "Putin's Brain". ${ }^{104}$ In their view, Dugin's ideas gained in popularity during the 2000 s mirroring Putin's own transition from apparent democrat to authoritarian. When Putin recognized the attractiveness of Dugin's ideas to many Russians, he seized on some of them to further his own goals. ${ }^{105}$ Dugin's role seemed to be limited, however, although he became a sort of cult figure and is probably the most well-known advocate of Russia's expansion. For a long time, he was considered politically marginal and his position at Moscow State University in June 2014 was discontinued with the publicly declared reason that the "university is a place for science and not for politics". 106

102 Alexander Astrov and Natalia Morozova, 'Russia: Geopolitics from the Heartland', in Guzzini (ed.), The Return of Geopolitics in Europe? 192.

103 Vladimir Zhirinovsky, Poslednii brosok na yug [The Final Thrust to the South] (Moskva: Pisatel' Bukvitsa, 1993).

104 Anton Barbashin and Hannah Thoburn, 'Putin's Brain: Alexander Dugin and the Philosophy Behind Putin's Invasion of Crimea', Foreign Affairs (31 March 2014), available at: \{https://www.foreignaffairs.com/articles/russia-fsu/2014-03-31/putins-brain\}, accessed 31 January 2019.

105 Ibid.

106 See, for example, 'Aleksandr Dugin uvolen iz MGU', Vesti (28 June 2014), available at: $\{$ http://www.vesti.ru/doc.html?id=1735926\}, accessed 31 January 2019. 
Dugin's ideas gathered nevertheless a lot of attention. ${ }^{107}$ Dugin has developed his ideas in many books such Osnory geopolitiki. Geopoliticheskoe budushchee Rossii, (1997) and other writings. ${ }^{108}$ In his writings, Dugin combined ideas of classical Western geopolitics, such as the eternal struggle between the Land and Sea Power, maritime (talassokratiya) and continental civilizations (tellurokratiya), with those of inter-war Eurasianist emigrants who believed that Russia is a unique civilization representing the Eurasian heartland. Dugin hence argues that continentalism and empire-building are the Russians' destiny, and Russia should therefore expand and become a new continental empire that opposes Atlanticism, globalisation, market-based economy, liberalism, and the foremost power that advocates all these, the United States. For Dugin, the Ukrainian crisis was part of this struggle between these two civilizations that were dividing the country. ${ }^{109}$ Moreover, Dugin represents classic organic thinking of territorial growth. In his view, the boundaries of Russia

should keep growing up to the moment when they cannot grow anymore. We've reached moments when we could not grow, we fall, and after that, each time in our history, we grow more. Our empire is a kind of heart, a beating heart with systoles and diastoles. I think Eurasia is our natural boundary. We won't touch England or Western Europe. ${ }^{110}$

The idea on building a new Russian empire is not limited to Dugin and his followers. One key figure of such imperial nationalists is the writer Aleksandr Prokhanov who has advocated the birth of 'the Fifth Empire' after four earlier in the history of Russia. ${ }^{111}$ These protagonists are often somewhat vague in defining the exact borders of the empire, but typically it comprises at least the current Eurasian Economic Union. If there is an argument justifying the empire, it is based on the idealization of the empire as a state form and the idea that the small independent countries are not able to survive and flourish alone.

107 For example, Marlène Laruelle, Russian Eurasianism. An Ideology of Empire (Washington, DC: Woodrow Wilson Center Press, 2008); Anton Shekhovtsov and Andreas Umland, 'Is Aleksandr Dugin a Traditionalist? "Neo-Eurasianism” and Perennial Philosophy', The Russian Review, 68 no. 4 (2009), 662-678.

108 See, for example, James Heiser, 'The American Empire Should be Destroyed': Alexander Dugin and the Perils of Immantized Eschatology (Malone: Repristination Press, 2014).

109 'Aleksandr Dugin: Krym dolzhen byt' v avangarde Russkogo mira', Novorossiya (4 August 2014), available at: $\{$ novorossia.su/ru/node/4781\}, accessed 31 January 2019.

110 Alexander Dugin, 'Russian Identity and Putin', Geopolitica.ru (22 November 2017), available at: $\left\{\right.$ https://www.geopolitica.ru/en/article/russian-identity-and-putin\}, accessed $3^{1}$ January 2019.

111 Aleksandr Prokhanov, Pyataya imperia [The Fifth Empire] (Moskva: Eksmo, 2007). 
Russia's official discourse when it comes to such geopolitical justifications in a general sense has been rather negative, although many liberals detect a continuing influence of an empire complex in Russia. ${ }^{12}$ Russian leaders have taken distance from the imperial nationalists and averred that might is not right: neither superior nor growing power, nor the concept of natural borders are valid justifications for territorial annexations and border changes. Putin has emphasized that Russia has and will have no imperial ambitions hinting that such ambitions would be neither rational nor popular. ${ }^{113}$ In contrast, in the Russian discourse it is the United States that is accused of classical geopolitical goals of striving for domination. ${ }^{114}$

Although Eurasianist and other imperial geopolitical programs have been part of the discourse in Russia, they were neither the mainstream nor the official rhetoric of the Kremlin. ${ }^{115}$ Dugin's views gained ground before the annexation of Crimea, but his direct influence remained marginal and the Kremlin soon distanced itself from his thinking. The geopolitical discourse in Russia has mainly served a national purpose and imperial visions have not been formulated as general principles for justifying territorial changes.

6

Historical Rights

Historical rights are almost always marshalled in favor of border changes when territorial claims are made. ${ }^{116}$ There are two basic forms of argumentation based on historical rights: the idea of first occupation, and the illegal or wrongful transfer of the territory in the past. Although such motivations can

112 For example, Emil Pain, 'Will Russia Transform Into a Nationalist Empire?', Russia in Global Affairs, no. 2 (2005), available at: \{http://eng.globalaffairs.ru/number/n_4954\}, accessed 31 January 2019.

113 Vladimir Putin, 'V.V. Putin vsretilsya s chlenami mezhdunarodnogo diskussionnogo kluba "Valdai"' [V.V. Putin met with members of the Valdai International Discussion Club], (11 September 2008), available at: $\{\mathrm{http} / / /$ archive.government.ru/docs/1897/\}, accessed 31 January 2019.

114 See e.g. Ruslan Dzarasov, "Interesy SShA v Evrazii i Ukraine" [US interests in Eurasia and Ukraine], Mezhdunarodnaya zhizn' (2015), available at \{https://interaffairs.ru/jauthor/ material/1370\}, accessed 31 January 2019 .

115 See also, Alexander Astrov and Natalia Morozova, 'Russia: Geopolitics from the Heartland', in Stefano Guzzini (ed.), The Return of Geopolitics in Europe?, 192-216.

116 Alexander Murphy, 'Historical Justifications for Territorial Claims', Annals of the Association of American Geographers, 8 o no. 4 (1990), 531-548. 
be appealing in a nostalgic or moral sense, they have rather clearly been excluded as convincing arguments in the current status quo regime.

As already mentioned, some historical borders have often been seen as 'natural' for Russia, but there has been no single historical era that would be favored as constituting the historical right. Czarist Russia as of 1917 is one such point in time, and the Soviet Union of 1991 may also be used as a historical reference. Many geopolitical narratives of the Russian state that have formed part of the rhetoric date back much further, even as far as medieval Kievan Rus. ${ }^{117}$ The most contested historically are the Soviet borders, however. Putin's statement that the dissolution of the Soviet Union was the greatest geopolitical catastrophe of the 2oth century ${ }^{118}$ was not an argument for territorial changes, but it chimed with such motivations because the wider political elite had not abandoned the nostalgia for a greater Russia of some description. ${ }^{119}$

The decision to annex Crimea was forcefully justified on historical grounds along with the principles of self-determination and the need to protect the rights of Russians. In his March 18 speech to the Duma, Putin explained how "in people's hearts and minds, Crimea has always been an inseparable part of Russia". The territory was not only historically Russian, but the way Crimea had become part of Ukraine was even more unjust: "Then in 1954 a decision was made to transfer the Crimean Region to Ukraine along with Sevastopol despite the fact that it was a federal city [...] What matters now is that this decision was made in clear violation of the constitutional norms that were in place even then. The decision was made behind the scenes". When Ukraine gained independence in 1991, it constituted an "outrageous historical injustice" to Crimea and the Crimean people, who were treated "like a sack of potatoes".120

Despite Putin's strong rhetoric, the doctrine of historical rights justifying territorial changes did not become part of Russia's policy otherwise, and it has

117 Serhii Plokhy, Lost Kingdom: The Quest for Empire and the Making of the Russian Nation (New York: Basic Books, 2017).

118 Vladimir Putin, 'Poslanie Federal'nomu Sobraniyu Rossiiskoi Federatsii' [Address to the Federal Assembly] (25 April 2005), available at: \{http://kremlin.ru/events/president/ transcripts/22931\}, accessed 31 January 2019.

119 See, for example, Sirke Mäkinen, Russian Geopolitical Visions and Argumentation. Parties of Power, Democratic and Communist Opposition on Chechnia and NATO, 1994-2003, Acta Universitatis Tamperensis 1293 (Tampere University Press 2008); Alan Ingram, 'Broadening Russia's Borders? The Nationalist Challenge of the Congress of Russian Communities', Political Geography, 20:2 (2001), 197-219.

120 Vladimir Putin, 'Obrashchenie Prezidenta Rossiiskoi Federatsii' [Address by President of the Russian Federation], (18March 2014), available at: \{http://kremlin.ru/events/president/ news/20603\}, accessed 31 January 2019. 
remained rather vague as a principle. With regard to Eastern Ukraine, Putin also employed historical argumentation. In the "direct line" interview, he said: "I would like to remind you that what was called Novorossiya (New Russia) back in the Tsarist days - Kharkov, Lugansk, Donetsk, Kherson, Nikolayev and Odessa - were not part of Ukraine back then. These territories were given to Ukraine in the 1920 by the Soviet government. Why? Who knows?"121 Elsewhere, he also referred to the territories transferred from Poland and Hungary to Ukraine. ${ }^{122}$ Yet Putin did not make any territorial claims on that basis and the whole concept of Novorossiya was subsequently avoided. ${ }^{123}$ Although it seems that the historical motivation was essential in the Crimean case, Russian representatives did not elaborate on when such historical rights would give rise to territorial changes elsewhere. There was no attempt to build a general doctrine or suggest a new border regime on the basis of historical rights. Paradoxically, on the basis of the Crimean case alone, it would seem that a country that has voluntarily (although 'illegally') transferred a piece of territory to another entity in the past has a stronger claim on it than if that piece had been forcefully seized.

Moreover, nationalists can claim that the historical rights of Russia cover the whole of Ukraine. For example, Duma deputy Gennadi Zyuganov from the Communist Party has argued that Ukraine is an inseparable part of both Russian (russkii) consciousness and Russian (rossiiskii) history. As a consequence, Russia needs to protect the unity of "our civilizational space, historically formed and which has existed around Russia for centuries".124

In particular, Russia has not given any hint of historical rights existing with regard to current Russian territories that have belonged to other states in the past. In the dispute over the Kuril Islands with Japan, the Russian position is that the prior ownership of the islands is irrelevant: instead, it has urged Tokyo to recognize the results of the Second World War. ${ }^{125}$ In fact, the history of such

121 Vladimir Putin, 'Direct Line with Vladimir Putin', (17 April 2014), available at: \{http:// en.kremlin.ru/events/president/news/20796\}, accessed 31 January 2019.

122 Putin, "Meeting of the Valdai International Discussion Club."

123 John O'Loughlin, Gerard Toal and Vladimir Kolosov, "The Rise and Fall of "Novorossiya": Examining Support for a Separatist Geopolitical Imaginary in Southeast Ukraine', PostSoviet Affairs 33 no. 2 (2017), 124-144.

124 Georgii Muradov, "Transformatsiya miroustroistva i perspektivy razvitiya evraziiskoi integratsii. Krimskii kontekst" [Transformation of the World Order and Prospects for the Development of Eurasian Integration - the Crimean Context], Mezhdunarodnaya Zhizn' no. 1, (2015), 143-149, here p. 144.

125 Maria Tsvetkova, 'Russia calls on Japan to recognize outcome of World War Two', Reuters (16 January 2019), available at: \{https://www.reuters.com/article/us-russia-lavrov-japan/ 
territories is sometimes depicted as if they had always been part of Russia. For example, in the speech that Putin delivered on the occasion of the Celebrations of the 75oth Anniversary of Kaliningrad, he made no reference to the German background of the city, stating instead that "it was here that our first contacts with European countries began".126

In general, Russia has not acknowledged views on historical rights in other cases in the world as a cause for border changes. Typically, such rights are only referred to when they are harnessed in support of the existing status quo, as in the case of Kosovo for example, where Russia supported the Serbian view that the territory was the historical heart of Serbia. Sometimes the principle of historical rights can be read between the lines when Western countries are criticized for their double standards. For example, the Russian representative to the UN, Vitaly Churkin, said that Britain should "clear its conscience" by "giving back" the Falklands and Gibraltar before it passes judgment on the Kremlin's annexation of Ukraine's Crimean Peninsula. ${ }^{127}$ One case where Russia may have formulated its position on a historical basis with regard to the border question is the Palestine issue. Russia has consistently supported Palestine's prerogative to create its own independent state with pre-1967 borders, regarding it as Palestinians' legal right, as well as a way to stabilize the region. ${ }^{128}$ Moreover, an isolated attempt to refer to the historical rights of other nations occurred in 2014 when Zhirinovsky approached Polish, Hungarian and Romanian embassies in Moscow and suggested having referenda in those regions of Ukraine that had formerly been part of the corresponding countries

russia-calls-on-japan-to-recognize-outcome-of-world-war-two-idUSKCNiPAoWV $\}, \quad$ accessed 31 Janaury 2019.

126 Vladimir Putin, 'Speech at the Celebrations of the 75oth Anniversary of Kaliningrad', Kaliningrad (2 July 2005), available at: \{http://en.kremlin.ru/events/president/transcripts/23071\}, accessed 31 January 2019.

127 Tom Parfitt, 'Give back Gibraltar before criticising us, says Russia', The Times (4 February 2017), available at: \{https://www.thetimes.co.uk/article/give-back-gibraltar-before-criticising-us-says-russia-8scvm32ng\}, accessed 31 January 2019.

128 See, Dmitri Medvedev, 'Dmitry Medvedev sent a message of congratulations to President of the State of Palestine and Chairman of the Palestinian National Authority Mahmoud Abbas on the Day of Solidarity with the Palestinian People' (28 November 2008), available at: $\{$ http://en.kremlin.ru/events/president/news/2256\}, accessed 31 January 2019; and Vladimir Putin, 'Ego Prevoskhoditel'stvu gospodinu Mahmudu Abbasu, Prezidentu Gosudarstva Palestiny' [His Excellency Mr. Mahmoud Abbas, President of the State of Palestine] (29 November 2014), available at: \{http://kremlin.ru/events/president/letters/ $47110\}$, accessed 31 January 2019 . 
to ask whether they wished to leave Ukraine and reunite with their former 'masters.' ${ }^{129}$

In sum, historical rights were very strongly brought to bear in the Crimean case in the official rhetoric. Yet such justification was seldom used in the official discourse before the annexation of Crimea other than in a very ambivalent and nostalgic way, and it has not been used more widely in international territorial conflicts. On the contrary, Russia has objected if others have used it.

\section{Conclusions}

Despite the annexation of Crimea, Russia's official discourse on territorial changes and the legitimacy of existing borders has not changed dramatically since the break-up of the Soviet Union. On the one hand, Russia has not abandoned the status quo regime as a key principle of international territorial order. On the other hand, reformist discourses justifying border changes on the grounds of self-determination, geopolitics, and historical justice have always been present in one form or another in the Russian discourse. What changed in the context of the Crimean annexation is that they were incorporated into the discourse of the state leadership for a short while. They did not, however, form a new doctrine beyond the case of Crimea. To a great extent, the political leadership did not invent a new discourse but leaned on arguments put forward by nationalists and communists that were marginalized during the 1990 s and early 2000 s.

Likewise, support for the status quo of borders and the territorial integrity of sovereign states in line with the commitment to principles of international law in general has dominated Russia's official discourse when it comes to international crises and conflicts involving a territorial dimension. Russia has not developed and articulated an alternative stance on an international border regime that would defend territorial changes in a general sense on the basis of geopolitical rights, self-determination, or historical justice. Rather, such doctrines have been ad hoc and marshalled in support of Russia's position in a few chosen cases, but not as a general rule that would be accepted independently of whoever is making the claim. The non-recognition policy still applies to secessionist movements around the world, including Republika Srpska, Nagorno-Karabakh, and Transnistria, as well as Kosovo. Against this

129 For example, 'Zhirinovsky predlozhil Polshe podelit Ukrainu', [Zhirinovsky suggested Poland to divideUkraine], $B B C$ (24March 2014), available at: \{http://www.bbc.com/russian/ international/2014/03/140324_zhirinovsky_poland_ukraine\}, accessed 31 January 2019. 
background, the recognition of South Ossetia and Abkhazia, plus Crimea, are exceptions that have not been singled out by a coherent doctrine. In this sense, Russia has adopted the same "double standards" that it has been so quick to accuse the West of. Relatedly, the dominant discourse has become more ambivalent than before, particularly with regard to the right to self-determination. Moreover, official positions notwithstanding, the Kremlin has allowed and supported unofficial campaigns in favor of separatist movements in the West.

If the discourse on borders and territorial questions did not change before the annexation of Crimea, to what extent can it explain Russia's policy? If the mere existence of discourse containing arguments for justifying territorial changes renders territorial annexations imaginable and therefore possible, then we could say that such discourse existed on the fringes for the most part. Yet the stronger claim that the dominant discourse would determine the adopted policies does not hold in the Russian case since arguments for territorial change were only marginal in the public discourse prior to the annexation of Crimea. In that sense, one could conclude that the domestic discourse in Russia made the policy of the annexation of Crimea possible, but it did not push the Kremlin to act. There was, of course, a latent sentiment pointing toward the popularity of territorial annexation as far as Crimea was concerned, but it did not manifest itself in the dominant public discourse (what has been said and argued in private can be another matter). Since the discourse related to the principles of territorial change has not changed since 2014 either, Russia's policy could be interpreted as a response to the perceived Western practice of territorial integrity and borders, namely tit-for-tat after which the old principles of territorial integrity would apply again.

\section{Acknowledgments}

The authors would like to thank Academy of Finland Project 'Cultural Statecraft in International Relations: The Case of Russia' (Project no. 298883, 20162020) and the Academy of Finland Centre of Excellence on Choices of Russian Modernisation (2012-2017) for financial support as well as Julia Bethwaite and Elena Gorbacheva for research assistance. We are also grateful to comments we received from the participants of the panels at the Aleksanteri Conference 2014 in Helsinki and at the ICCEEs World Congress 2015 in Makuhari where earlier versions of this article were presented. 